\title{
Making Museums Relevant in a World of Diversity
}

Rita Paqualén

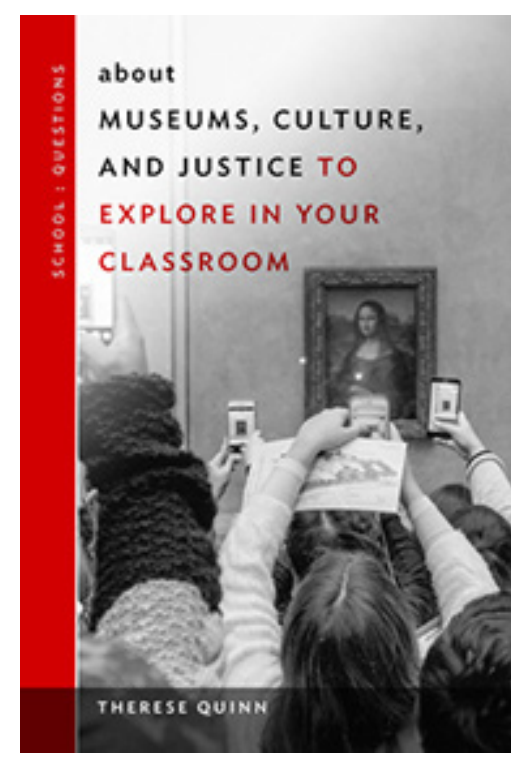

Therese Quinn.2020.School: Questions about Museums, Culture, and Justice to Explore in Your Classroom. School: Questions series. Teachers College Press. New York \& London, 96 pages.

In her new book About Museums, Culture, and Justice to Explore in Your Classroom Associate Professor Therese Quinn critically analyses the role of the museums in today's world and discusses how teachers can use museums in order to teach students critical thinking and social justice. Combining critical museology with pedagogics the book offers theoretical approaches to the museum as an institution and examples on museum interventions and artivism around the world, as well as hands-on tools and projects through which students can engage with the museums and their collections. As Quinn is based in the United States, most of her examples and arguments come from the North American art and culture context, but she also includes many exciting cases and museums from other parts of the world and, also, outside the Western world.
The book consists of ten chapters. In the first chapter "Introduction: Are Museums for Everyone?" Quinn claims that the mostly or partly publicly funded museums belong to us. Yet museums "are underused and undervalued" (2) and they are, in opposition to libraries, "often actually or perceptually inaccessible" and "located in special districts, charge admissions, feature monolingual programming” (3). Furthermore, museums "fail when they aren't honest about their histories and don't tell the stories of people of color, immigrants, and others who are underrepresented in cultural spaces" (5) and they are "still segregated workplaces, with whites now holding $84 \%$ of curator, conservator, and educator positions" (6).

This starting point, the notion that museums should belong to us, yet fail to do so due to their historical roots linked colonialism, social exclusion, and race segregation, is the guiding principle throughout the book. Therese Quinn shows on the one hand why museums need to redefine themselves, and on the other hand how students can make use even of the failures of the museums, in assignments related to self-definition, agency, and critical thinking. Thus, the book suggests "that museums should be seen as public resources that can offer rich extensions to classroom educational practices" (7) - even in cases when the museums fail their task to represent the community and its diverse history. 


\section{The Western amnesia}

With the following chapters, "Who Made the First Museum?" and, "Why Do Museums Collect?", the book continues to focus on the traditional role of the museums as the sites for collecting and exhibiting history. In these two chapters Quinn analyses on the other hand colonial roots of the collecting practices of Western museum institutions, and on the other hand the amnesia and ignorance of the same institution, when it comes to attributing inventions or ideas to marginalized groups or social movements - even regarding its own history. Despite the desire of the Western museum historians to find museum's roots in Europe, "the world's first public museum was started in the 6th century BCE by Bel-ShaltiNanna, also known as Ennigaldi, a princess living in Babylonia, a state in central Mesopotamia" (11).

By using Ennigaldi and the feminist art pieces, The Dinner Party (1974-79) by the artist Judy Chicago and 129 collaborators and its parody, The Box Lunch (1979) by the artist Maria Manhattan as her examples, Quinn shows how contributions and art made by women, especially women of colour, has been undervalued, ignored and discredited in the museums, but also that we need intersectional approaches when critically engaging with museums. The history of the museum collections is not only linked to colonial expansion and the exclusion of women, but also to class, ethnicity, and other kinds of privileges and exclusions.

\section{Museums as a starting point for social resistance}

The colonial history of the collections is further addressed in chapter "What Have We Learned from the Past and About the Present That Can Help Us Shape the Future?” from the viewpoint of the recent calls by activists, artists, and museum workers to decolonize the museums. The decolonization of the institutions starts by the recognition of Native communities as the original inhabitants of the land, but decolonizing is also about sharing power, unsettling, and rethinking the processes of the museum practices. The decolonialization of the museums involves in many cases repatriating the stolen goods to the indigenous communities and/ or former colonies. This movement can also be seen in Finland, where the National museum has during the past years started two repatriation processes, one concerning the Sámi cultural heritage, and another one about excavated bones and skulls from the graves of Pueblo people in Masa Verde, Colorado.

Quinn notes that decolonization is a verb and "requires action, making it a rich concept and process to explore with students" (32). The chapter regarding decolonizing processes marks a turning point in the dramaturgy of the book. Whereas the first three chapters can be seen as laying the ground and describing the traditional role of the museum, this fourth chapter and the following ones are more focussed on giving tools for museums to become more inclusive. Likewise, they suggest practices for students (and anyone else for that matter) for rethinking museums in questions regarding decolonialization, accessibility and equity. It is about becoming an active and critical visitor and a potential worker of the museums. Through this becoming they challenge the museum to become more open and an active participant in the work for an equal and democratic society.

The question of the role of museums in social struggles is raised in the chapter "How and When Should Museums Respond to Everyday Events?", where Therese Quinn discusses two concrete cases in which museums have responded to police violence and killings of African American men. Quinn notes that museums are by no means neutral places, and that they should 
be prepared to take stance and publicly address injustice. Yet, as one of her museum cases shows, museums can be unprepared for the consequences of such actions. In her classroom exercises she suggests activities through which students can try out different methods through which museums could respond to urgent social issues.

\section{From a museum for the few to a museum for the many}

Becoming a museum for all and not only for the few, demands conscious work in order to make it accessible, inclusive, and relevant. These issues are addressed from a visitor's perspective especially in chapter "How Can Museums Welcome All Bodies?”, "How Can Museums Celebrate LGBTQ People's Lives and Contributions?" and "Why Do We Pay to Visit Museums?”. In these chapters Quinn analyses questions regarding accessibility and inclusion in the museums from an intersectional perspective, and quotes the disability scholar and artist Sunaura Taylor (2017), who claims that access is always intersectional and "isn't only about physical space, [but] also about the economic and social systems that structure society" (41). In these chapters Quinn combines perspectives on accessibility with questions related to queer and ethnicity, and she introduces creative exercises through which students, for example, are encouraged try out different accessibility tools and to explore the limitations and possibilities of museums from a crip/queer perspective when it comes to representation and social inclusion.

In order, for museums to become more relevant for the underrepresented groups, it is not enough to focus on the visitors, we also need to focus on the museum institution in itself. One of the most important chapters, in my view, are chapters "What Is It Like to Work in a Museum?" and "What Can Museum Practices Teach Us About Collaborating and Sharing
Authority?" that focus on who is working and who tells the stories in the museum. As long, as the museum workers and curators continue to be mainly white, able-bodied and cis-gendered, and the national narrative heteronormative, the museums continue to tell the story of the privileged few. Therese Quinn notes that in order for a real change to occur, it is not only enough that teachers encourage students from various backgrounds to pursue a museum career, we also need to talk about job conditions. She reminds us, that " $[\mathrm{b}]$ eing able to do jobs we love is a luxury, something that is not possible for everyone-maybe only those who can afford to do unpaid internships" (60).

Associate Professor Therese Quinn's book About Museums, Culture, and Justice to Explore in Your Classroom is a rich source of inspiration, not only for rethinking the role of museums and how to make them more inclusive, but especially for seeing museums as a potential source for teaching about social justice and for encouraging students to become critical and resisting readers of the knowledge and narratives the museums offer. She notes that " $[\mathrm{w}]$ hile museums lag in centering the stories of queer people and movements, they still offer many entry points for teaching to and about social justice, while linking the past and present to a shared and queered future" (69). 